\title{
BOMBS, BODIES, AND GHOSTS: NAVIGATING \\ RHETORICAL LEGACIES OF NUCLEAR TECHNOLOGY IN RECENT CARIBBEAN SCIENCE FICTION
}

\author{
Bombas, cuerpos y fantasmas: explorando el legado retórico \\ de la tecnología nuclear en la ciencia ficción caribeña
}

\author{
SAMUEL GINSBURG \\ WASHINGTON STATE UNIVERSITY (Estados Unidos) \\ samuel.ginsburg@wsu.edu
}

\begin{abstract}
This article examines the rhetorical power of nuclear weapons, and how recent Caribbean science fiction has challenged popular nuclear archives. Dominican author Rey Emmanuel Andújar's story "Gameon" (2014) speculates on the environmental, human, and geopolitical effects of nuclear war. Next, Cuban author Yasmín Silvia Portales's story "Las extrañas decisiones de Vladimir Denísovich Jiménez" (2016) asks if there is a place for queerness within a power structure based on nuclear supremacy. Finally, Cuban author Erick Mota's novella Trabajo Extra (2014) uses radioactive materials to discuss labor exploitation and alternative modes of development. These texts challenge colonizing nuclear rhetoric by creating spaces for proper mourning and remembrance.

Keywords: Caribbean Science Fiction, Nuclear Technology, Dominican Republic, Cuba, Techno-colonialism
\end{abstract}

Resumen: este artículo analiza el poder retórico de las armas nucleares y la forma en que la ciencia ficción reciente ha desafiado los populares archivos nucleares. El relato "Gamenon" (2014), del autor dominicano Rey Emmanuel Andújar, reflexiona sobre los efectos medioambientales, humanos y geopolíticos de la guerra nuclear. Además, el relato "Las extrañas decisiones de Vladimir Denísovich Jiménez" (2016), de la autora cubana Yasmín Silvia Portales, se pregunta si existe un lugar para lo queer en el marco de una estructura de poder basada en la supremacía nuclear. Finalmente, la novela Trabajo extra (2014), del autor cubano Erick Mota, usa material radioactivo para debatir la explotación en el trabajo y modelos de desarrollo alternativos. Estos textos desafían la retórica nuclear colonizadora en la medida que crea espacios para el recuerdo y el duelo. Palabras clave: ciencia ficción caribeña, tecnología nuclear, República Dominicana, Cuba, tecno-colonialismo 
On April 14, 1948, Rafael Trujillo held a groundbreaking ceremony for the Faro a Colón, or Columbus Lighthouse, a monument, museum, and mausoleum commemorating Columbus's arrival to the Americas. While the planning of this monument, including an international architecture competition, had started before he came to power, Trujillo saw the massive project as symbol of the Dominican Republic's European, Christian, and capitalist ideals, and as a way to publicly display this historical link to Columbus on an international stage. As Edgardo Rodríguez Juliá writes in his 1992 crónica "La isla al revés", Trujillo contracted Puerto Rican physicist Amador Cobas to design a nuclear detonator for the inauguration of the building site (108). Less than three years after the United States' devastating bombings of Hiroshima and Nagasaki, the Dominican president saw the use of nuclear weapons for construction as a symbol of Western progress: "Por impulso de la fuerza nuclear desgarramos la superficie de la tierra para la construcción de este monumento, utilizando por primera vez en la historia ese fin destructor en un propósito de paz y fraternidad" [powered by nuclear force we will tear open the earth's surface for the construction of this monument, utilizing for the first time in history this destructive end for a purpose of peace and fraternity.] (108). In a sign that the regime was more prepared for the symbolism of nuclear weapons than their actual repercussions, Trujillo then watched as the enormous rocks shot into the air from the explosion came crashing down on the hood of Vice President Manuel Troncoso's car (108). According to Rodríguez Juliá, the embarrassment from this episode dissuaded the notoriously superstitious Trujillo from pursuing the project any further (107). Whether it was because of that explosion, World War II, or Trujillo's desire to commemorate his own successes over anything else, the construction of the lighthouse did not resume until 1986, during Joaquín Balaguer's regime.

Trujillo's call for harmony and goodwill at the ceremony went against the dictator's violent actions and policies. The elevation of this historical connection to Christopher Columbus reflected Trujillo's reliance on promoting the Dominican Republic's whiteness in nationalist discourse, complemented by a racist antihatianism. This monument to Columbus fit well into Trujillo's educational policies at the time, which emphasized Christian civilization and Hispanic tradition, along with minimizing and justifying the massacre of thousands of Haitians in 1937 (Sagás, 2000: 61-2). The use of nuclear technology can also be connected to this desire to promote whiteness on a national stage. Paul Williams (2011) critiques the racially coded language of nationhood, civilization, modernity, and terrorism both in official discourse on nuclear war and in many mainstream literary or cinematic representations. Williams argues that nuclear weapons are popularly understood as sources of white power "because the weapons themselves symbolize the achievements, atrocities and attitudes of European and American modernity," and "because the post-nuclear-war future that such weapons could make possible is deemed to reproduce a (European) colonial or (American) frontier dynamic" (15-6). Wittingly or not, Trujillo's desire to exhibit control over nuclear weapons aligns 
with his goals of promoting whiteness and placing the Dominican Republic in a lineage of European civilization.

Nuclear technology is weaponized in many ways: larger-than-life explosions, silent radiation, or even the mere hypothetical threat of its use. Fear of unforeseeable future devastations or ongoing repercussions from past exposures contribute to the power of nuclear weapons within structures of techno-dominance. The socio-technological network of popular narratives creates a nuclear archive that informs the public's relationship to the technology; this collective archive effects how nuclear events are remembered, how victims are mourned, and how survivors are understood. This article examines the ways in which science fiction can reshape and contest the colonizing rhetoric and narratives surrounding the historical deployment of nuclear weapons in the Caribbean. The three texts studied here-Rey Emmanuel Andújar's "Gameon" (2014), writer Yasmín Silvia Portales's "Las extrańas decisiones de Vladimir Denísovich Jiménez” (2016), and Erick Mota's Trabajo Extra (2014)_push past sublime explosions and mushroom clouds to create a more honest nuclear archive. These texts recognize and combat the rhetorical legacies of nuclear weapons in the Caribbean, creating spaces for proper mourning, recovery and survival.

The most notable event in Caribbean nuclear history is the Cuban Missile Crisis, known in Cuba as the Crisis de octubre. From October 16 until October 28, 1962, the United States and Soviet Union veered dangerously close to nuclear war, due to a delivery of Soviet missiles to Cuba in response to the US missiles already stationed in Turkey. Fidel Castro later admitted that he was shocked by how large the weapons were: "Nosotros no sabíamos ni cómo era un cohete de esos, ni qué tamaño tenía, ni dónde había que instalarlo, ni por dónde se disparaba, porque si nosotros hubiésemos sabido cómo eran los cohetes esos...qué fácil habría sido tomar una decisión" ["We didn't know what one of those rockets was like, nor what size it was, nor where to install it, nor from where it shot, because if we had known what those rockets were like, it would have been easy to make a decision."](Castro, 1968: 84). This break between the power of nuclear rhetoric and the danger of the actual weapons highlights the fact that much of the technologies' power is based on language and performance. As Jacques Derrida (1984) argued, "Just as all language, all writing, every poetico-performative or theoretico-informative text dispatches, sends itself, allows itself to be sent, so today's missiles... allow themselves to be described more readily than ever as dispatches in writing (code, inscription, trace, and so on)" (29). This conceptualization of nuclear war as textual also recognizes the power of the socio-technological narratives that surround nuclear technology; speculations are invented to create a space for nuclear war (such as the invention of an enemy that can only be defeated through nuclear intervention) or to prevent it from happening (such as public fears over the long-term health and environmental effects of radiation). Recognizing text's role in the deployment or deterrence of nuclear war highlights the importance of studying how popular narratives and rhetoric surrounding nuclear weapons contribute to the technology's power. 
According to Tomás Diez Acosta's Octubre de 1962: un paso del holocausto (2002), Soviet leader Nikita Khrushchev understood the implications of placing such powerful technology so close to the United States, saying: "Tenemos que pagarles con la misma moneda, darles a probar su propio remedio, y obligarlos a sentir en su propio cuerpo lo que significa vivir colmados por armas nucleares" [we have to pay them with the same currency, give them a taste of their own medicine, and make them feel in their own body what it means live flooded with nuclear weapons] (90). This quote stands out because, while the nuclear missiles were to be pointed at the US, it was the Cubans that were actually surrounded by this volatile technology. Cuba was ultimately left out of the negotiations that put an end to the 13-day nuclear showdown; this quote suggests a disregard for the political and physical dangers put on the Cuban people. In another notable moment, Diez Acosta quotes Khrushchev as reassuring skeptical Cuban officials by saying, "No te preocupes, yo voy a coger a Kennedy por los testículos" [don't worry, I am going to grab Kennedy by the testicles] (98-9). Khrushchev frames this potentially devastating conflict as a challenge of masculinity, emphasizing the role of hyper-masculine rhetoric and anxieties within military actions. Carol Cohn (1993) argues that hypermasculine perspectives and an aversion to all seemingly feminine language among defense intellectuals makes it difficult to discuss or deliberate nuclear outcomes other than massive destruction and death. Cohn writes, "What gets left out, then, is the emotional, the concrete, the particular, the human bodies and their vulnerability, human lives and their subjectivity-all of which are marked as feminine in the binary dichotomies of gender discourse" (232). The hypermasculine rhetoric and symbolism that increases the chances of nuclear disaster has also been deployed in official memory projects around the Missile Crisis. This mix of triumphant rhetoric and embarrassment towards Cuba's secondary role in the negotiations makes this moment a key point of departure for Caribbean nuclear fiction.

While the Cuban Missile Crisis remains central to Caribbean nuclear history, popular opinion and narratives surrounding nuclear weapons have also fueled the debate over techno-colonialism in Vieques, Puerto Rico, home to a US Navy base from 1941 to 2003. High levels of cancer on the island and the dangers of radiation became primary talking points in the protests to shut down the base, as debates over radiation intensified in the mid-1990s (Baver, 2006: 105). This focus on physical health, led by women activists on the island, was an essential step towards pushing out the Navy, as demonstrators could no longer be accused of anti-patriotism (Kadalie, 2009: 107). However, the dismissal of the military has not completely calmed fears of US colonial interference and coverup. Since the closing base, the US Fish and Wildlife Service designated most of that land as a wildlife refuge. Many residents of Vieques mistrust the fact that the land remains under federal control and believe that its status blocks nongovernmental researchers from learning more about the continued environmental effects (Davis et al., 2007: 177). Nuclear techno-colonialism and environmental-scientific rhetoric appear to collude against the people of Vieques 
who seek answers. David Kupferman (2015) writes, "The erasure of survivance and prolepsis of victimhood...totalizes the experience of the nuclear-affected other, not the least result of which is the denial of the face (and face to face) of survival in its binary dance with that of victimization" (12). This is a doubly colonizing outcome of the deployment of nuclear war: dominant power is established through the nuclear event, and then that same power is reinforced through the official institutions that control historical records and shape public archives.

As the ultimate symbol of the dangers of the human push for dominance over technology and science, a number of Latin American science fiction writers have incorporated conversations about nuclear weapons into their work. Recent Latin American texts (both science fiction and not) that discuss the dangers and aftermaths of nuclear disaster include Edmundo Paz Soldán's Iris (2014) and Liliana Colanzi's Nuestro mundo muerto (2018) from Bolivia, Subte (2012) by Argentine writer Rafael Pinedo, Chernóbil (2018) by Mexican writer Iliana Olmedo, and "Intensidad líquida" (2005) by Iván Molina Jiménez of Costa Rica. Still, this previously mentioned Caribbean nuclear history has seemingly inspired an overwhelming number of texts-- both in the genre of science fiction and within other narrative styles- - that negotiate legacies of nuclear technodominance. The list of recent Caribbean texts that include nuclear technology or apocalyptic destruction includes Abel Fernández-Larrea's Absolut Röntgen (2009), Yoss's story "Ese día..." (2011), Pedro Cabiya's poem "Hiroshima" (2014), Elaine Vilar Madruga's Culto de Acoplamiento (2015), and Brenda Peynado's The Radioactives (2017). The three science fiction texts chosen for this article all investigate different aspects of nuclear technology, from explosions and radiation to the structural and social changes within a techno-colonial system built on the threat of nuclear war. Rey Emmanuel Andújar's "Gameon" (2014) focuses on the ecological impact of nuclear weapons and how such disasters make room for colonizing powers. Yasmín Silvia Portales's story "Las extrañas decisiones de Vladimir Denísovich Jiménez" (2016) looks at the colonial and social effects of nuclear war, and whether there is a place for queer bodies in a post-nuclear society. Erick Mota's novella Trabajo Extra (2014) delves into the ongoing dangers of radiation and imagines an escape from nuclear techno-colonialism that evokes alternative modes of progress. By inserting themselves into the popular nuclear archive, these texts push back against the ongoing legacy of colonizing nuclear narratives and rhetoric. At the same time, by alluding to past near-apocalyptic events and the ongoing dangers of exposure, the fictions analyzed here create a space for effected bodies and places to be recognized and remembered. Patrick Sharp (2007) argues that politically engaged nuclear fictions should highlight and challenge the gendered and racially coded narratives and rhetoric that advance large-scale techno-dominance: "They should remind us of the dangers of unchecked racism, militarism, and nationalism and keep us vigilant against the never-ending stream of distortions and outright lies disseminated by our leaders" (223). The power of nuclear science fiction comes from its ability to provide warnings and potential worst-case scenarios, while also forcing the reader 
to reconsider their relationships to technological development and technonationalist rhetoric.

While nuclear fictions may predict future disasters, they can also rewrite histories and imagine possible outcomes of past threats. One such text is "Gameon" (2014), by Dominican writer and performer Rey Emmanuel Andújar. Though Andújar, winner of the 2008 Pen Club of Puerto Rico Book of the Year for Candela (2007), does not primarily write science fiction, "Gameon" was published as part of a special section on science fiction in Contratiempos, a Chicago-based literary magazine that promotes Spanishlanguage writing in the city. The story's focus on the environmental effects of technology also classifies it as climate fiction (cli-fi), an increasingly popular literary field that delves into climate change and corresponding environmental disasters. Cli-fi has become particularly useful to discuss techno-dominance in the Caribbean, due to the belief that smaller islands will be first to suffer from rising water levels caused by the environmental sins of larger economic and political superpowers. As Lizabeth Paravisini-Gebert (2010) writes, "The rapid deterioration of the environment in the Caribbean region, which has taken place within the lifetime of many of its residents, has led to a 'sense of ending,' to the apocalyptic dread of a potential ecological disaster that can erase the islands, their peoples, and cultures" (114). This 'sense of ending' has led to a number of fictional takes on the future of Caribbean environmentalism. Recent Caribbean science fictions that could be classified as cli-fi include Nuria Dolores Ordaz Matos's novel Entremundos (2010), Tomás Piard's film La noche del juicio (2010), Rafael Acevedo's novel Al otro lado del muro hay carne fresca (2014), Jorge Enrique Lage's novel La autopista: the movie (2014), and Alejandro Rojas Medina's Chunga Maya (2017). While texts like Andújar's "Gameon” attempt to highlight the dystopic futures that are becoming more and more plausible, there are still questions as to the impact that fiction can have on environmental policy and activism.

"Gameon" is a meta-literary text, first describing the narrator's failed attempt at writing a science fiction story, and then recounting a made-up nuclear novel entitled Gameon, written by fictional author Lester Dakeng. The narrator at the beginning of the story is uneasy about writing science fiction, but ultimately decides to try because he is an adjunct professor in the middle of summer and needs the money. "Gameon" takes the form of a personal essay and book review, making it possible to fit an entire science fiction world into just a single page. According to Andújar's story, Dakeng's Gameon imagines a world in the aftermath of a nuclear incident, in which "la crisis de los misiles en Cuba no fue evitada" [the missile crisis in Cuba was not avoided] (23). Andújar's story repositions the Missile Crisis as a conflict between Cuba and the United States, instead of a US-Soviet clash that manipulated the Castro regime as a pawn in a much larger global struggle. This reframing emphasizes the fact that if missiles had been launched, Cuba would have felt the subsequent retaliation more than the Soviet Union. Highlighting the dangers that the Cuban people risked as two 
larger world powers and the Cuban government played political games is a step towards a clearer history of nuclear techno-dominance in the Caribbean.

In Andújar's version of the Missile Crisis, when Cuba launched the rockets, the US deployed an ectoplasmic shield that protected the country from most of the effects of the nuclear weapons. Referencing a history of US technocolonialism in the region, this shield increased the damage done by the missiles to the Caribbean region: "En cuanto al Caribe, el escudo actuó como reflejo, así que las islas recibieron una dosis doble de radiación" [as for the Caribbean, the shield acted like a mirror, so that the islands received a double dose of radiation] (23). The Caribbean islands and people feel the brunt of the impact from the nuclear strike, showing the risks of ever launching nuclear weapons, especially at such a close target. In the story, nuclear weapons represent an uncontrollable power that is as likely to affect those that deploy them as much as the intended target. In the US, while the shield mostly did its job, some radiation did manage to seep through: "Aunque el daño fue disminuido por la resistencia del escudo protector, el sur quedó afectado para siempre" [although the protective shield diminished the damage, the South would be forever affected] (23). By naming casualties on both sides of the conflict, "Gameon" highlights the repressive biopolitics that span borders and regions, making visible the victims often ignored by nuclear narratives that represent these conflicts as ideological or diplomatic clashes.

Not only does the reflection of radiation off of the American shield affect the Caribbean people, but it also contaminates the Caribbean Sea and transforms it into "algo comparable a una caldera de ácido" [something comparable to a cauldron of acid] (23). Soon after the attack, the sea begins to consume the island territories, redrawing the Caribbean map and creating the newly named Archipiélago Vivisector. Like the Caribbean Sea, the Gulf of Mexico was irreversibly destroyed by the nuclear radiation, now occupied by "una suerte de infierno de lava y granizo que flotaba como un hoyo negro" [a sort of inferno made of lava and hailstones that floated like a black hole] (23). This ecological disaster creates a physical barrier between the Caribbean and the United States that only a small number of specially equipped ships can cross. As in many other texts on nuclear weapons and power, nature itself seems to be revolting against humanity, possibly in response to the human hubris that chose to manipulate its natural elements and laws. This image of a black mass in the middle of the Gulf of Mexico also may recall the 2010 Deepwater Horizon oil spill, also known as the BP oil spill, in which an estimated 5.9 million barrels leaked into the water. By alluding to this moment in the socio-technological history of the region, "Gameon" highlights the possible extractive, corporate, and geopolitical interests that could predetermine or worsen natural disasters in the Caribbean and emphasizes the gap between those that control nuclear technologies and those left to negotiate its repercussions.

While the main focus of this story is the ecological and human fallout from a failed nuclear attack, Andújar also notes how these issues cannot be separated from their political effects. As Arundhati Roy (2003) and others have 
suggested, nuclear weapons are not just dangerous due to physical damage, but also for the political repressions that may be carried out under the guise of public security or defense when nuclear war is a possibility. She writes, "The threshold of horror has been ratcheted up so high that nothing short of genocide or the prospect of nuclear war merits mention...Displacement, dispossession, starvation, poverty, disease-these are now just the funnies, the comic-strip items" (4). This same issue appears in "Gameon," as the United States takes advantage of the postnuclear confusion to expand its territory, taking control of half of Mexico and signing a treaty with Canada to unite the two countries into one national entity. The time-bending nature of science fiction allows authors like Andújar to both reference the Cuban Missile Crisis in the 1960s and allude to the later implementation of NAFTA, signed in 1989. In the story, the missile attack gives the US an excuse to intensify its already rampant military, economic, and cultural imperialism in the Americas; as the Caribbean islands are devoured by the acidic sea, the United States continues to expand its territory and influence. This new super-nation is renamed Warfar, a land of perpetual war. Andujar's representation of Warfur reflects what John Louis Lucaites and Jon Simons (2017) refer to as the paradox of war's in/visibility in the $21^{\text {st }}$ century, creating "a public culture in which war is continuous and altogether present, but largely unseen and/or unacknowledged" (3). While domestic policies and rights are greatly affected by specters of outside threats and calls for national security, the nearconstant deployment of fighting abroad is normalized and ignored. By reimagining a post-nuclear US as Warfar, Andújar's text highlights the ways in which the perpetual war paradigm reshapes the nature of citizenship and nationhood.

Andújar ends his story by returning to the narrator's situation as an underpaid adjunct professor, connecting nuclear dehumanization to the exploitation of scholars within an academic system increasingly influenced by neoliberalism: "No terminaré nunca a tiempo el cuento para la revista, me quedaré pegado con la lectura de Gameon y sus quijotadas nucleares. El verano agotará sus posibilidades y yo mitigaré el hambre pensando en el libro perdido de Lester Dakeng" [I will never finish the story for the magazine on time, I will stay stuck to the reading of Gameon and its quixotic nuclear acts. The summer will run out and I will mitigate my hunger thinking of Lester Dakeng's lost book] (23). More than a glorification of the escapist power of fiction, the narrator's musings on his own hunger follows what Herb Childress (2019) refers to as adjunctification's damage beyond low pay and a lack of opportunities, the "fear, despair, surrender, shame...the messy, hidden human elements that finance and policy always miss" (159). While this reference to contingent faculty and academic precarity may feel out of place in a short story about nuclear war and environmental disaster, it could also be read as a signal to readers to reconsider the more banal ways in which marginalized subjects are kept down. In this way, the destruction of higher education can be just as devastating as a sublime explosion, as destructive power can be deployed through university budget allocations as well as nuclear missiles. 
Different from Andújar's post-nuclear ecological disaster, Cuban author, science fiction scholar and activist Yasmín Silvia Portales's reimagining of the Cuban Missile Crisis in "Las extrañas decisiones de Vladimir Denísovich Jiménez" (2016) focuses on the political and colonial implications of the appearance of nuclear weapons on the island. The story imagines a young diplomat from present-day Cuba who falls into an alternate version of Havana in a parallel universe, where they are a trans woman named Vania. While the causes behind this inter-dimensional travel are never explained, the story finds Vladimir on the day before he is set to travel back to Moscow, presumably for them to debrief and then dispose of him. When asked if Moscow would allow them to return to their own world, Vladimir answers, "No me dejarían, aunque pudieran. Sé demasiado. Quieren mis conocimientos, no ayudarme" [they wouldn't let me go, even if they could. I know too much. They want my knowledge, not to help me] (246). Vladimir spends their last night with their sister Tamara, her husband Guennadi, and Iván. To Vladimir's surprise, they and Iván are lovers in this alternate world, even though they are brothers in the original one. Most likely linked to Portales's own social activism, including her founding of the online platform Proyecto Arcoiris in 2011, there is a particular focus in the story on the treatment of and spaces for queer bodies under this post-nuclear regime.

"Las extrañas decisiones de Vladimir Denísovich Jiménez" only includes one reference to nuclear weapons, when Vladimir notes that in this alternative world the Cuban Missile Crisis marked the "pérdida de la soberanía cubana" ["loss of Cuban sovereignty"] and island's transformation into a Soviet colony (241). As Castro had feared in real life, Portales imagines a world in which Cuba's role as weapon holder and ideological pawn cleared the path for the Soviet Union to take full control of the country. Despite only this fleeting mention of the technology, this text is read here as what scholar of Russian science fiction Anindita Banerjee (2016) has coined as contaminated fiction, which "deploys the nuclear in an intimate set of relations that help make sense of the world after utopia and define what it means to be a subject in a precarious new order of the twenty-first century" (71). By focusing on these intimacies or relationships, as opposed to the techno-political institutions, contaminated fiction allows for a closer look into how nuclear war or disaster may reshape interpersonal connections. Banerjee continues, "Contaminated fiction thus provides a powerful way for bridging the discursive spheres of the real, imagined, lived, and speculative potentials of nuclear power" (71). This contamination or bridging is similar to the way that radiation can silently reconfigure the most basic biological or social building blocks. As a text that travels back and forth between present-day Havana and a post-nuclear version, "Las extrañas decisiones de Vladimir Denísovich Jiménez" folds together real and imagined impacts of the Cuban Missile Crisis, highlighting nuclear technology's ability to infiltrate popular language and memory.

Analyzing this story as contaminated fiction means that minor details can take on greater significance as insight into how Portales envisions a nuclear 
event would affect Cuban social and political systems. For example, Vladimir says that time in alternate Havana "era como mirar al abismo" [was like looking into the abyss] (235). This moment achieves new meaning when one considers how close the island came to suffer nuclear apocalypse. There are also clues as to how Cubans are treated by their Soviet colonizers. Vladimir mentions that nobody knew for sure if the imported gasoline they used contained lead, hinting at a lack of Soviet concern for the health and wellbeing of their subjects in Cuba (237). The subtlest detail comes when Vladimir and Tamara debate taking the streetcar to lunch. The Cuban streetcar system was actually dismantled in 1952, so it is notably that this modern-day, alternate version of Havana still uses them. What makes this detail a comment of nuclear techno-dominance is the fact that Cold War-era architects designed the Mosco metro system as both a model of Soviet modernity and a fallout shelter for possible future nuclear attacks. ${ }^{1}$ That these same projects were not extended to Havana makes clear the position that Cuba holds in this imagined nuclear empire.

On the surface, this alternate timeline shows a very different version of Cuba. Despite economic advances and the fact that foreign products are readily available to Cuban citizens, Vladimir asks, “¿Era mejor ser este Puerto Rico soviético que aquel país independiente y hambreado de donde venía él?” [was it better to be this Soviet Puerto Rico or that independent and hungry country from which he came?] (237). The question is not rhetorical; Vladimir seems to be honestly torn between the two possibilities. At the same time, this line draws a connection between the colonial history of Cuba and the current colonial occupation of Puerto Rico by the US. One of the biggest changes for Vladimir is that the restaurant Moscú is now a reservation-only establishment, with long lines of people trying to get a table. Vladimir finds this especially odd, since in his world he considers the restaurant to be a dilapidated embarrassment: "En su Habana, el edificio estaba hecho una ruina, nada más que se usaba por filmar escenas de ambiente post apocalíptico...se había convertido en lugar común de la filmografía que 'demostraba' el fracaso del Revolución Cubana" [in his Havana, the building was in ruins, used for nothing more than to film postapocalyptic background scenes... it had been converted into a common location for films that 'showed' the failures of the Cuban Revolution] (237). Portales offers a different take on the science fiction motif of post-apocalyptic futures, proposing that the future of techno-dominance may look more like present-day San Juan and less like recent dystopic imaginings of Cuba's future, such as in the films Omega-3 (2014) and Los desastres de la guerra (2012). This moment also brings up the role of film in creating both dystopic and utopic narratives of Cuba. As Ana María Dopico (2002) argues, internationally distributed apocalyptic or dystopian images of Cuba fulfil an "ethnovoyeuristic fantasy": "The cultural tourist experiences firsthand (and all at once) the fruit of revolution, third-world lifestyle, and a living experiment in disaster, apocalypse, and survival. The allure of Cuba lies precisely in both its suffering and its surviving collapse” (463). The

\footnotetext{
${ }^{1}$ See Banerjee (2016) for more on Moscow's metro and its representation in Russian science fiction.
} 
formation of popular culture imagery of what an apocalypse or dystopia should look like helps obscure the dystopian acts being carried out under the guise of shiny, sleek technological progress.

After recounting the violent battle for socialism mostly fought by Soviet colonial subjects, Portales connects this violent disregard for Cuban soldiers with an equally problematic treatment of queer people within the alternate Soviet empire. As mentioned above, Vladimir is shocked to find out that while Ivan is their brother in the original world, the two of them are lovers in this new one. This fact is especially complicated in this new Soviet version of Havana. Portales writes, "Por supuesto, estaban en territorio de la URSS, y la homosexualidad era una de las enfermedades que se trataban con electroshocks — si se descubría en la adolescencia - o agresivas terapias de reconversión — si la víctima tiene más de veinte. No ser gay era la mejor opción" [of course, they were in Soviet territory, and homosexuality was one of the illnesses that was treated with electroshocksif it was discovered in adolescence-or aggressive reconversion therapies-if the victim was over 20 years old. Not being gay was the best option] (241). Not only is queerness not accepted in this world, it is understood as an illness that merited intense and violent treatment. This is a double reference, to both the current official homophobia by the Russian government, and also to Eduardo Gutiérrez Agramonte's experiments in the 1960s on electroconvulsive therapy as a cure for homosexuality. Referencing this horrific history as part of a post-nuclear future highlights Portales's critique that the Cuban government in general and Mariela Castro's CENESEX in particular have not yet done enough to atone for the past treatment of gay Cubans, including the infamous UMAP labor camps. ${ }^{2}$ In 2016, Portales was outspoken over the official censorship of the online Cuban LGBT community that she founded, Proyecto Arcoiris. The site was shut down after a post by Jimmy Roque Martínez (2015) criticized the continued official homophobia within Cuba, such as the lack of legal standing for homosexual families (Abd'Allah-Alvarez Ramírez). By alluding to Cuba's violent, homophobic past, Portales points out the ways in which these legacies are perpetuated, along with literature's role in maintaining public memories of moments that the official archive would like to erase.

Though Vladimir feels the danger of being queer in this new world, they are also surprised to find out that they and Ivan had secretly been together for a decade. With the help of Tamara and Guennadi, Ivan and Vladimir have managed to both maintain their relationship and hide it in public. This is aided by the lack of available housing in Havana, also an issue in present-day Cuba, which allows the two of them to live together without raising suspicion. Vladimir also notes that their secret is also protected by "la familiaridad con que los varones cubanos se trataban en público, una intimidad inimaginable en Europa Oriental" [the familiarity with which Cuban men treated each other, an intimacy unimaginable in Eastern Europe] (241). In their words, Cuban men are more likely to initiate physical contact with others, hiding any underlying sexual

\footnotetext{
${ }^{2}$ For more on the history of official Cuban homophobia, see Bejel (2001).
} 
desires. Vania had chosen to return to Cuba after studying in Moscow for this reason, under the guise of wanting to reconnect to his roots. By highlighting the latent homoeroticism within the homophobic, post-nuclear colony, this story also contests the militarized masculinity of Cuba's New Man and the heteronormative rhetoric that supports nuclear war. Vladimir suspects that many young Soviet officials have chosen to be stationed in Cuba for similar reasons and mentions a queer colony in Matanzas. These details allude to Cuba's emergence as an international destination for queer tourism, a fact that both shows the progress that the country has made and its attempts to obfuscate a dark history of official homophobia. Noelle Stout (2014) argues that due to international media representations of Cuba and state policies that segregate locals from tourists, queer tourism often paints a utopian image of Cuban anti-homophobia, confusing the tourists privileged position with a widespread official acceptance of queerness (146-8). Potales's portrayal of alternative Cuba as a gay refuge highlights the role of revolutionary rhetoric and international marketing in the obfuscation of the historical record.

As Vladimir grows increasingly comfortable with themself as Vania, they begin to question whether or not they may be trans in all possible universes, and if they have been forced to repress this realization in old Cuba. It stands out that the protagonist may feel more comfortable identifying as trans in this repressive Soviet colony than in present-day Cuba, despite the country's publicized progress and openness towards the trans community. ${ }^{3}$ While nuclear technology attempts to impose heteronormative and hyper-masculine models of dominance, Vania's presence disrupts the ideal, masculine public servant that Vladimir had once represented. Despite having found comfort and happiness in Vania and with Ivan, Vladimir decides to swim off by themself into the ocean instead of traveling back to the Soviet Union. By killing themself instead of facing official rebuke in Moscow, Vladimir deprives the Soviet authorities of valuable knowledge. It is difficult to say whether or not Vladimir's decision to commit suicide could or should be understood as an act of agency. Instead, this move offers insight into the social and political structure that surrounded them. As Achille Mbembe (2003) writes, "under the conditions of necropower, the lines between resistance and suicide, sacrifice and redemption, martyrdom and freedom are blurred" (40). Vladimir believed that there was no official place for a queer body within this post-nuclear world, a colonial system based on the aggressive power of two feuding states whose combined global hegemony is sustained by a dominance over nuclear weapons that thrives off of conformity and heteronormativity. Though Vania and Ivan were able to navigate the cracks within the system for some time, the former ultimately decides that they no longer belong in any universe.

${ }^{3}$ Mariette Pathy Allen's Transcuba (2014) provides many interviews with trans Cubans that highlight their appreciation of Mariela Castro's CENESEX initiatives and the ongoing difficulties that they face. 
While Andújar and Portales reimagine past near-disasters, Cuban author Erick Mota's Trabajo Extra (2014) describes a distant future in which human bodies are still being affected by nuclear techno-dominance. Mota, who is most well-known for his 2010 stories/novel Habana Underguater, has won a number of Cuban science fiction prizes, including Juventud Técnica (2005), La Edad de Oro (2007), and Calendario (2008). Mota first introduced the cadets Kay Hunter and Juan Tomás Kirk as they navigate both their training and their misgivings about the government they serve in the novella Bajo Presion (2008). The second publication in the "Kirk y Kay" storyline was Historias del cosmos salvaje (2014), comprised of two novellas, El último vuelo del Cid and Trabajo Extra. In Trabajo Extra Kirk looks to make extra money over a school break, navigating an old ship with a group of other students to dump containers of nuclear waste in a less inhabited part of the universe. Instead of the action-packed battle scenes of a traditional space opera, Trabajo Extra tells the story of the mishaps that happen during this supposedly routine mission, and how Kirk manages to get everyone back alive. However, in the background there are larger discussions on technocolonialism and the effects of nuclear accidents.

In Mota's novella, there is a noticeable lack of outrage or concern from the crew over the dangerous nature of their nuclear cargo. While each of them has reservations about joining the mission, they cite issues with the ship or a lack of trust in the other crew members, but never question the safety of transporting radioactive materials. Only Kay tries to warn her friend, saying, “Еso es explotación, Kirk! Se aprovechan de nosotros para hacer un trabajo realmente peligroso e ilegal. Trabajar con radiactividad puede costarnos las vidas" [that is exploitation, Kirk! They take advantage of us to do a really dangerous and illegal job. Working with radioactivity could cost us our lives] (76). To highlight how undeterred the cadets are by the nuclear cargo, there is much more frustration when they find out that the ship was also secretly carrying a load of synthetic beer, deemed illegal contraband by the ruling power in the galaxy, la Flota. Though Mota's novella does not directly reference the Cuban Missile Crisis, there is a similar mark of the uneven power relationship between those in control of nuclear technology and those in close contact with it.

The colonizing influence of la Flota has a great impact on the mistrust between crewmembers. Everyone on the ship attempts to manipulate or hide something about their identity, either to distance them from or connect them to the center of power. The hiding of identities and origins based on socioeconomic hierarchies has grave consequences in the case of Ripley, the ship's head engineer. Ripley claims to be from a large planet, since that is understood as more honorable than being born on one of la Flota's many terraformed asteroids. This attempt at respectability backfires when approaching the nuclear cargo during a spacewalk reignites her radiation poisoning. Only then is it revealed that Ripley grew up on UGM-12, the site of an infamous nuclear disaster. When Ripley was 11 , a nuclear warhead accidentally exploded in a dock on UGM-12 that was being subcontracted by la Flota. After the explosion, nuclear waste seeped into the asteroid and made it uninhabitable. Ripley, who 
was still undergoing treatments for radiophobia, held this information back because prior exposure should have disqualified her from the mission. Kirk, who is sympathetic to her issues but also annoyed that she lied to get on the ship, refers to Ripley as a refugee and adds, "Nadie puede entrar en un infierno como ese con once años y esperar a los veinte que todo esté bien" [nobody can enter an inferno like that at age 11 and expect at 20 for everything to be fine] (108). Ripley's inability to speak openly about her past underlines the ways in which nuclear rhetoric silences living victims of such disasters. Her backstory also alludes to the 1986 explosion at the Chernobyl Nuclear Power Plant, which has a unique place in Cuban cultural memory, as tens of thousands of children affected by that nuclear accident have been treated in Tarará, a resort-turnedpediatric hospital outside of Havana (Schipani). Even after the mission, Kirk notes that Ripley remained affected by this incident and that she "terminó quebrándose ante el fantasma de la radioactividad" [ended up breaking down in the face of the ghost of radioactivity] (139). This moment demonstrates the power of nuclear rhetoric to make proper mourning and rehabilitation impossible.

After coming into contact with the radiation, Ripley cannot stop mumbling about cosmic rays, Geiger counters, mutant flowers, and radioactive eyes (107). In an attempt to calm her down, Sakura accidentally gives her too much of a sedative and nearly causes an overdose. This mistake causes Sakura to retreat to her cabin for the rest of the mission. The pressure from the mission pushes Rada to drink too much synthetic beer, leaving Kirk to manage the entire ship all by himself. He must navigate and fly the ship at the same time, while also repairing the outdated engine as it sputters on the way home. While Kirk is not an engineer, he reassures himself that "las máquinas siempre son máquinas...Primero se les apaga para que se calmen. Luego se les vuelve a encender. Si para entonces persiste en no funcionar, se les da un par de golpes y listo" [machines are always machines...First turn it off so that it calms down. Then turn it on again. If then it still doesn't work, hit it a few times, and ready to go] (118). This ability to work with machines recalls the narratives of technological resourcefulness that have often been used to describe the Cuban people, most commonly in reference to their ability to refurbish and maintain ageing automobiles. As Louis A. Pérez Jr. (2018) writes, "This is Cuba mired in circumstances of unrelenting hardship offered as a source of nostalgic delight and photogenic objects of a sightseer gaze... a people living under impoverished material circumstances whose plight as a historical condition is marketed as a sightseeing attraction" (20). That cadets may be similarly rigging up spaceships in the future highlights the rhetorical legacies of these narratives and the globalizing forces that promote them.

Kirk uses a similar ingenuity when his navigation system fails, coming up with a plan to launch the ship in short spurts to different parts of the universe until he can manually devise their location. During this process, Kirk accidentally stumbles upon a massive community of the Pioneers, self-exiles that refused to live under la Flota's repressive system. The Pioneers had been thought 
of as non-human, mythical beings that preferred zero gravity and attempted to create self-sufficient habitats, untethered from planets and asteroids. Kirk explains:

Claro que eran humanos...Su piel era más oscura por la sobre exposición de los rayos UV de los reactores iónicos. Eran inmunes a la radiación y la necesidad los había enseñado a no confiar en las inteligencias artificiales. Pero perdieron una guerra contra la humanidad de los Mundos. La historia que nos leímos fue contada por los vencedores, por los humanos de las biosferas y la gravedad. [Of course they were humans...their skin was darker due to over-exposure to the UV rays from the ionic reactors. They were immune to radiation and necessity had taught them to distrust artificial intelligence. But they lost a war against the humanity of the Worlds. The history that we read was written by the victors, by the humans of the biospheres and gravity] (115).

Kirk's fascination with the Pioneers says a lot about his relationship with nuclear techno-dominance. Kirk notes the role that official histories have on marginalized or defeated groups, and how attempted innovations can be written off as foolish deviations from dominant understandings of technological progress. He also acknowledges the legitimacy of mistrusting advanced technology like artificial intelligence, especially when those tools are used for surveillance or weaponry. Kirk's reference to the Pioneers' darker skin turns their escape from the Fleet into a sort of cosmic cimarronaje, a term that describes the fleeing and establishment of alternative communities by Afro-descendent slaves. Instead of rejecting the technologies used to repress them, the Pioneers selectively take advantage of their benefits in an effort to remove themselves from colonial networks of power. Trabajo Extra suggests that such a rupture relies on the reconceptualization of our relationship to natural resources, and of technology's role in providing for humankind in a more democratic manner.

Kirk, as a military academy cadet, is legally obligated to inform the authorities about this unauthorized habitat. He knows that upon being discovered, the civilization would quickly be destroyed. Kirk goes back and forth over what the right thing to do is, not wanting to wipe out such a marvel but also acknowledging that more people could benefit from their technology. While he attempts to file a report just before the ship is about the move again, he loses connectivity before it can be sent; it is unclear if this is on purpose or not. On his long journey back, Kirk imagines the notoriety he could achieve by being the first to discover such a place, though he sees the ridiculousness in taking credit for a discovery that would lead to the destruction of millions of people. Despite the temptation of fame and glory, by the time Kirk returns to the academy, he decides not to tell anyone about his discovery other than his best friend Kay. Kirk's resolution to shirk his responsibility to la Flota allows the Pioneers to continue their alternative path of technological development and emphasizes the capacity for individual agency within a militarized chain of command.

Mota's Trabajo Extra forces readers to remember the effected bodies that cannot escape their nuclear pasts, those haunted by the ghosts of radiation. These 
bodies are often forgotten in the narratives that shape memories of weaponized nuclear technology. Similarly, Portales inserts the stories of queer bodies into the nuclear archive, highlighting the hyper-masculine and heteronormative nature of nuclear rhetoric. Vladimir's suicide sadly highlights the lack of space for queerness in a world shaped by nuclear hegemony. Finally, Andújar's "Gameon" forefronts the irreversible environmental effects of nuclear strikes, along with how military campaigns and extractive technologies that alter or mutate nature can also reconfigure global politics. All of these texts contest and reshape the archive of narratives that weaponize nuclear technologies even before any missiles are launched, while also creating space for proper mourning and understanding of the equally disastrous aftereffects.

\section{WORKS CITED}

ABD'Allah-Alvarez Ramírez, Sandra (2016), "Plataforma estatal cubana censura bitácora sobre diversidad sexual”, Global Voices. Consultado en: $<$ https://es.globalvoices.org/2016/02/07/plataforma-estatal-cubanacensura-bitacora-sobre-diversidad-sexual/> (21/12/2020).

ACEVEDO, Rafael (2014), Al otro lado del muro hay carne fresca. La Secta de los Perros. ANDÚJAR, Rey Emmanuel (2007), Candela. Alfaguara.

ANDÚJAR, Rey Emmanuel (2014), Gameon. Contratiempo, 115, 23.

BANERJEE, Anindita (2016), "From fallout fantasy to bunker bildungsroman: Nuclear imagination after utopia", Foundation, 45.2(124), 70-84.

BAVER, Sherrie (2006), "Peace is more than the end of bombing": The second stage of the Vieques struggle, Latin American Perspectives, 33(1), 102-115.

BEJEL, Emilio (2001), Gay Cuban nation. The University of Chicago Press.

CASTRO, Fidel (1968), Fragmentos de la intervención del Comandante en Jefe Fidel Castro en el pleno del comité central del partido comunista de Cuba, 25-26 de enero 1968.

Consultado en: <https://digitalarchive.wilsoncenter.org/document/110767> (21/12/2020).

CABIYA, Pedro (2014), "Hiroshima". Consultado en: <http://www.pedrocabiya.com/2014/06/hiroshima/> (21/12/2020).

CHILDRESS, Herb (2019), The adjunct underclass: How America's colleges betrayed their faculty, their students, and their mission. The University of Chicago Press.

COHN, Carol (1993), "Wars, wimps, and women: Talking gender and thinking war”, en Miriam Cooke and Angela Woollacott (Eds.), Gendering war talk Princeton University Press, pp. 227-246.

COlANZI, Liliana (2018), Nuestro mundo muerto. Editorial El Cuervo.

DAVIS, Jeffrey Sasha; HAYES-COROY, Jessica S., and JONES, Victoria M. (2007), "Military pollution and natural purity: Seeing nature and knowing contamination in Vieques, Puerto Rico", GeoJournal, 69(3), 165-179. 
DEL LlANO, Eduardo (Director) (2014), Omega 3 [Film]. ICAIC.

DerridA, Jacques; PORTER, Catherine, and LEWIS, Philip (1984), "No apocalypse, not now (full speed ahead, seven missiles, seven missives)" Diacritics, 14(2), 20-31.

DiEZ AcosTA, Tomás (2002), Octubre de 1962: un paso del holocausto: una mirada cubana a la crisis de los misiles. Editora Política.

DOPICO, Ana María (2002), Picturing Havana: History, vision, and the scramble for Cuba. Nepantla: Views from South, 3(3), 451-493.

FERNÁNDEZ-LARREA, Abel (2009), Absolut röntgen. Editorial Cajachina.

KADALIE, Mobido (2009), "The emergence of women in the leadership of a struggle for ecological justice: The case of Vieques”, Race, Gender \& Class, 16(3/4), 99-108.

KuPFERMAN, David W. (2015), "How 'natives' drink. Bravo shots, for example: Mourning and nuclear kitsch", Postmodern Culture, 25(3).

LAGE, Jorge Enrique, (2014), La autopista: the movie. Editorial Cajachina.

LUCAITES, John Louis, and Simons, Jon, (2017), In/Visible war: The culture of war in twenty-first-century America. Rutgers University Press.

MARTínEZ, Jimmy Roque (2015), "Con el perdón (o no) de Mariela Castro", Havana

Times. Consultado en: <https://havanatimesenespanol.org/diarios/jimmyroque/con-el-perdon-o-no-de-mariela-castro/> (21/12/2020).

Mbembé, Achille (2003), "Necropolitics", Public Culture (translated by Libby Meintjes), 15(1), 11-40.

MOLINA JimÉNEZ, Iván (2005), "Intensidad líquida”, en El alivio de las nubes: y más cuentos ticos de ciencia ficción. Auto-publicado.

Mota PÉREZ, Erick J. (2008), Bajo presión. Editorial Gente Nueva.

Mota PÉREZ, Erick J. (2010), Habana Underguater. Atom Press.

MOTA PÉREZ, Erick J. (2014), Historias del cosmos salvaje. Ámbar.

Olmedo, Iliana. (2018), Chernóbil. Siglo Veintiuno Editories.

Ordaz Matos, Nuria Dolores. (2010), Entremundos. Editorial Gente Nueva.

PARAVISINI-GEBERT, Lizabeth. (2010), "Caribbean utopias and dystopias: The emergence of the environmental writer and artist. In Adrian Tylor Kane" (Ed.), The natural world in Latin American literatures: Ecocritical essays on twentieth century writings (113-135). Mcfarland.

Pathy Allen, Mariette (2014), Transcuba. Daylight Books.

PAZ SOLDÁn, Edmundo (2014), Iris. Alfaguara.

PÉREZ JR., Louis A. (2018), "The nostalgia of empire: Time travel in Cuba", International Journal of Cuban Studies, 10(1), 8-29.

PEYNADO, Brenda (2017), The Radioactives. Day One.

PIARD, Tomás (Director), (2010) La noche del juicio [Film]. Instituto Cubano de Radio y Televisión.

PIARD, Tomás (Director) (2012), Los desastres de la guerra [Film]. Instituto Cubano de Radio y Televisión.

PINEDO, Rafael (2012), Subte. Editorial Salto de Página. 
PORTALES, Yasmín Silvia (2016), "Las extrañas decisiones de Vladimir Denísovich Jiménez", en Leonardo Gala (Ed.), Órbita Juracán: Cuentos cubanos de ciencia ficción. Editorial Voces de Hoy, pp. 231-246.

RodrígueZ Juliá, Edgardo (2002), Caribeños. Editorial Instituto de Cultura Puertorriqueña.

Rojas Medina, Alejandro (2017), Chunga Maya. Casa Editora Abril.

RoY, Arundhati (2003), War talk. South End Press.

SAGÁs, Ernesto (2000), Race and politics in the Dominican Republic. University Press of Florida.

SCHIPANI, Andres (2009), "Revolutionary care: Castro's doctors give hope to children of Chernobyl", The Guardian. Consultado en: <https:/www.theguardian.com/world/2009/jul/02/cuba-chernobyl-healthchildren> (21/12/2020).

SHARP, Patrick (2007), Savage perils: Racial frontiers and nuclear apocalypse in American culture. University of Oklahoma Press.

STOUT, Noelle M. (2014), After love: Queer intimacy and erotic economies in postSoviet Cuba. Duke University Press.

Vilar Madruga, Elaine (2015), Culto de acoplamiento. Editorial José Martí.

Williams, Paul (2011), Race, ethnicity and nuclear war: Representations of nuclear weapons and post-apocalyptic worlds. Liverpool University Press.

Yoss (2011), "Ese día...", en Raúl Aguiar (Ed.), Qubit: antologiá de la nueva ciencia ficción latinoamericana. Casa de las Américas, pp. 87-98. 